\title{
ANALISIS TINGKAT JANGKAUAN PELAYANAN PENGEMBANGAN MINIMARKET DI KORIDOR JALAN TERHADAP PERILAKU KONSUMEN Studi Kasus Koridor Jl. Semarang-Boja Kecamatan Mijen
}

\author{
Meika Deby Priyanka ${ }^{1}$; Eppy Yuliani ${ }^{2}$ \\ Program Studi Perencanaan Wilayah dan Kota Universitas Islam Sultan Agung Semarang ${ }^{1,2}$
}

\begin{abstract}
Minimarket is one form of retail trade continues to grow and spread rapidly in the neighborhoods and the corners of the big cities in Indonesia as well as business becomes the most expansive retail trade in Indonesia. Semarang as the capital of Central Java is also facing the phenomenon. One of the minienvironments where scattered settlements and significantly expand the District Mijen. Since the first minimarket outlets operating in the region in 2007 until February 2013 there have been 7 minimarket outlets operating. Research Question It can be concluded from this study is what the development of a minimarket in District Mijen can influence changes in consumer behavior in determining the location of shopping options?

The research methode used in this study using a quantitative deductive rationalistic. Based on questionnaire, interviews and observations, the identification and analysis techniques of quantitative descriptive analysis and interpretation of cross-tabulation analysis techniques among variables that were examined in the form of table analysis and chi-square crosstab.

The development of minimarket condition every day visitors who come around 300 people, with the total 7 minimarket mini market until 2013. Minimarket well as projected needs 10 years from now seen that the projected need for services in the District Mijen minimarket stated is sufficient to serve. Consumer behavior is largely based on the mini frequency of visits was done 2 times a week, daily necessities, distance and outlets are clean and organized is the biggest factor affecting the motivation of respondents to shop at the mini. Range of minimarket located in District Mijen is overlapped between the mini with the other minimarket. Distance range that is divided into the ring I 500 meters and ring II $1 \mathrm{Km}$. The need for evaluation of spatial planning through distribution pattern minimarket and community shopping destination location so as to anticipate the entry of modern retail in maintaining continuity of traditional retail (traditional retailers).
\end{abstract}

Keywords: minimarket, consumer behavior, and the range of services

\begin{abstract}
ABSTRAK
Minimarket merupakan perdagangan ritel yang terus tumbuh dan menyebar dengan cepat di lingkungan permukiman serta menjadi bisnis perdagangan ritel yang paling ekspansif di Indonesia. Kota Semarang sebagai ibukota Jawa Tengah juga menghadapi fenomena tersebut. Salah satu lingkungan permukiman dimana minimarket tersebar dan berekspansi cukup signifikan yaitu Kecamatan Mijen. Sejak gerai minimarket pertama di kawasan ini beroperasi pada tahun 2007 hingga februari 2013 telah terdapat 7 gerai minimarket yang beroperasi. Research Question dari penelitian ini adalah apakah adanya perkembangan minimarket di Kecamatan Mijen dapat mempengaruhi perubahan perilaku konsumen dalam menentukan lokasi pilihan berbelanja?

Metode penelitian yang digunakan dalam penelitian ini adalah deduktif kuantitatif dengan menggunakan pendekatan rasionalistik. Berdasarkan data kuesioner, wawancara serta observasi, dengan teknik analisis identifikasi dan analisis deskriptif kuantitatif serta interpretasi data melalui teknik analisis tabulasi silang antar variabel yang dikaji berupa data tabel analisis crosstab dan chi-square.

Perkembangan kondisi eksisting minimarket setiap hari pengunjung yang datang sekitar 300 orang, dengan jumlah minimarket yaitu 7 minimarket hingga tahun 2013. Serta proyeksi kebutuhan minimarket 10 tahun kedepan terlihat bahwa hasil proyeksi kebutuhan pelayanan minimarket di Kecamatan Mijen dinyatakan sudah cukup melayani. Perilaku konsumen minimarket sebagian besar didasari oleh frekuensi kunjungan dilakukan sebanyak 2 kali dalam seminggu, bahan kebutuhan sehari-hari, jarak dan gerai yang
\end{abstract}


bersih dan tertata merupakan faktor yang mempengaruhi motivasi terbesar responden untuk berbelanja di minimarket. Jangkauan dari minimarket yang terdapat di Kecamatan Mijen cenderung overlapping antar minimarket. Jangkauan pelayanan minimarket terbagi menjadi ring I 500 meter dan ring II 1 Km. Perlu adanya evaluasi penataan ruang melalui pola persebaran minimarket dan lokasi tujuan belanja masyarakat sehingga dapat mengantisipasi masuknya ritel modern dalam upaya menjaga keberlangsungan ritel tradisional (pengecer tradisional).

Kata Kunci: minimarket, perilaku konsumen, dan jangkauan pelayanan. 


\section{PENDAHULUAN}

Seiring berkembangnya zaman, maka pertumbuhan suatu daerah serta sektor perdagangan akan mengalami perkembangan secara pesat. Meningkatnya jumlah penduduk yang sangat pesat dapat menyebabkan peningkatan permintaan akan penggunaan lahan yang yang dimanfaatkan oleh berbagi aktivitas didalamnya, pemanfaatan lahan produktif harus dimaksimalkan oleh penguna lahan untuk mewadai pelaksanaan kegiatan produktif salah satunya yatu kegiatan perdagangan (Roinson, 2005 dalam Sari, 2012). Kegiatan perdagangan yang berkembang saat ini memacu jumlah peningkatan sarana perdagangan di suatu wilayah. Sarana kegiatan perdagangan salah satunya yaitu minimarket. Menurut Jones dan Simmons, 1990 dalam Aulia, dkk, 2009, minimarket merupakan bentuk sarana perdaganagn yang berfungsi sebagai tempat pemenuhan kebutuhan individu maupun keluaga yang pada umumnya berlokasi di dekat permukiman warga sebagai target pasarannya.

Pada kenyataannya bahwa dalam sistem perdagangan tentunya akan ada produsen dan konsumen dimana produsen sebagai pelaku dalam menjual maupun memproduksi barang, sedangkan konsumen sebagai pelaku yang membeli dan mengonsumsi barang yang dijual oleh produsen. Sementara itu yang akan dibahas kali yaitu terkait perilaku konsumen, definisi dari perilaku konsumen yaitu studi tentang bagaimana individu, kelompok, maupun organisasi dalam memilih, membeli, memakai, dan peran dari suatu barag, jasa, ide, atau pengalaman guna memberi kepuasan pada kebututuhan dan keinginan dari konsumen (Kotler dan Keller, 2009 dalam Dewi, dkk)

Survei yang dilakukan AC Nielsen mengungkapkan pertumbuhan pasar tradisional menyusut hingga $8,1 \%$ setiap tahunnya sedangkan pasar modern tumbuh $31,4 \%$ per tahun. Masuknya minimarket ke pinggiran kota ini sedikit demi sedikit mempengaruhi perilaku belanja konsumen. Minimarket menjadi bagian dari ritel-ritel atau toko modern yang membangun strategi dalam mengembangkan usahanya di kota-kota kecamatan, pinggiran kota, desa-desa, bahkan ke plosok-plosok, keadaan ini memberikan keuntungan kepada pemilik minimarket untuk mengembangkan usaha dikarenakan di daerah perkotaan sudah banyak hypermarket dan supermarket besar sehingga strategy ini dikembangkan dengan sengaja guna mendekati sasaran konsumen aktif yaitu penduduk yang bermukim (Rusli, 2011) .Perlu digaris bawahi apakah penyediaan minimarket juga disertai dengan permintaan yang berimbang (supply-demand) atau terjadi penyediaan fasilitas berlebihan sehingga dapat meninggikan daya saing antara retail modern dengan pedagang tradisional. 
Research Question dari penelitian ini adalah apakah adanya perkembangan minimarket di Kecamatan Mijen dapat mempengaruhi perubahan perilaku konsumen dalam menentukan lokasi pilihan berbelanja?

Penelitian ini bertujuan untuk mengetahui perkembangan minimarket terhadap perilaku konsumen yang ada di Koridor J1. Semarang - Boja, Kecamatan Mijen, Kota Semarang. Dalam mencapai tujuan dari penelitian ini, ada beberapa sasaran yang harus dilaksanakan yaitu :

a. Identifikasi kondisi wilayah Kawasan Mijen sehingga dapat diketahui karakteristik Kawasan Mijen;

b. Menganalisis perkembangan minimarket melalui analisis tahapan perkembangan dan analisis perilaku konsumen. Analisis tahap perkembangan ditinjau berdasarkan data kondisi eksisting minimarket berupa jumlah minimarket, tahun berdiri,jumlah pengunjung rata-rata serta proyeksi kebutuhan minimarket 10tahun kedepan. Sedangkan perilaku konsumen minimarket ditinjau berdasarkan variabel faktor pemintaan ritel yaitu lokasi, pendapatan, gaya hidup dan demografi di Kawasan Mijen;

c. Menganalisis Jangkauan pelayanan minimarket yang ditinjau dari variabel aksesibilitas dan jarak maksimum serta minimum dari minimarket di Kawasan Mijen.

\section{METODOLOGI}

Metode penelitian yang digunakan dalam penelitian ini adalah deduktif kuantitatif dengan menggunakan pendekatan rasionalistik. Menurut Muhajir (2000) dalam Priono 2013, penelitian dengan menggunakan metode kuantitatif berarti bahwa penelitian tersebut mengacu pada teori atau konsep yang dijadikan sebagai bingkai dalam penelitian. Kuantitatif dimaksud unuk menganalisis dengan cara menguur secara matematis istrumeninstrumen yang skalatis, sebagai contoh yaitu analasis secara statistic deskripif dan melakukan pengujian-pengujian khusus terhadap data nominal/angka. Sedangkan pendekatan rasionalistik yang dimaksd yaitu pemaknaan secara empiri untuk membangun ilmu yang dipikirkan dengan pemahaman secara rasional dan logis dengan didukung olh data yang empirik dan relevan.

Minimarket menerapkan sistem swalayan, dimana pembeli mengambil sendiri barang yang dibutuhkan dan membayarnya di kasir. Dengan adanya minimarket kebutuhan konsumen untuk belanja sedikit dengan tempat yang nyaman dan didekat rumah terpenuhi. Perilaku konsumen yang menyukai tempat belanja yang bersih, sejuk dan tertata rapi 
membuat minimarket mengungguli toko dan warung (Ma'aruf, 2005:84). Sedangkan berdasarkan Peraturan Presiden Nomor 112 Tahun 2007 tentang Penataan dan Pembinaan Pasar Tradisional, Pusat Perbelanjaan, dan Toko Modern, pengelola jaringan minimarket adalah pelaku usaha yang melakukan kegiatan usaha di bidang minimarket melalui satu kesatuan manajemen dan sistem pendistribusian barang ke outlet yang merupakan jaringannya. Minimarket mempunyai dua sistem operasinal yaitu sistem secara regular dan waralaba (Marina dan Setyono, 2012).

Menurut (Jones dan Simmon, 1993: 28) terdapat empat faktor yang mempengaruhi permintaan

a. Lokasi; Besarnya populasi dan karakteristiknya,Kedekatan dengan sumber pemasok,Ketersediaan tenaga kerja,Situasi persaingan, Fasilitas promosi,Ketersediaan lokasi toko,Hokum dan peraturan

b. Produk; Target market,Jenis gerai,Lokasi dimana gerai berada,Value chain,Kemampuan pemasok, Biaya,Kecenderungan mode produk

c. Harga; Besarnya laba yang akan diambil, Faktor pesaing

d. Atmosfer dalam gerai; Desain toko,Perencanaan toko,Komunikasi visual,Produk yang dijual

e. Pelayanan; Layanan pelanggan,Layanan transaksi,Fasilitas-fasilitas penunjang (toilet dan parkir)

\section{Perilaku Konsumen}

Perilaku konsumen adalah semua kegiatan, tindakan serta proses psikologis yang mendorong tindakan tersebut pada saat sebelum membeli, ketika membeli, menggunakan, menghabiskan produk dan jasa setelah melakukan hal-hal diatas atau kegiatan mengevaluasi (Sumarwan, 2004). Sedangkan pengertian perilaku konsumen menurut Mowen dan Minor (2002) dalam Marina dan Setyono (2012) adalah studi terkait unit pembelian (buying units) dan proses pertukaran yang melibatkan pendapatan, konsumsi, dan pembuangan barang jasa, pengalaman, serta pemikiran-pemikiran. Menurut (Philip Kotler dan Gary Armstrong, 2008) mengatakan terdapat 2 fakta perilaku konsumen, yaitu:

a. Faktor Pribadi

- Demografi yang menjelaskann mengenai umur, jenis kelamin, serta tingkat pendidikan;

- Pendapatan : tingkat pendapatan, jenis pekerjaan, serta pengeluaran belanja;

- Gaya Hidup : pola hidup seseorang yang tergambar pada motivasi, frekuensi; 


\section{b. Faktor Psikologis}

- Motivasi adalah kebutuhan yang mendorong sesorang secara kuat mencari kepuasan atas kebutuhan tersebut;

- Persepsi proses menyeleksi, mengatur dan menginterpretasikan informasi guna membentuk gambaran yang berarti;

- Pembelajaran: perubahan perilaku seseorang karena pengalaman;

\section{Pelayanan Konsumen}

Menurut Yanto (2013), pengertian dari pelayanan konsumen yaitu variabel retail image keempat yang dijadikan sebagai alasan pokok konsumen berbelanja di toko ritel, dimana produk yang dihasilkan oleh perusahaan yaitu berupa barang dan jasa atau layanan. Barang tersebut berbentuk fisik atau berwujud sehingga dapat dipegang, melainkan jasa tidak berwujud. Pelayanan yang diberikan kepada konsumen harus berkualitas dimana berkaitan dengan kemampuan dari kelompok atau organisasi dalam memenuhi serta melebihi harapan dari konsumen. (Payne, 2001 dalam Yanto, 2013)

\section{Jangkauan Pelayanan}

Jangkauan (range) adalah jarak maksimum/minimum yang ditempuh konsumen untuk memperoleh barang. Jadi jangkauan pelayanan untuk suatu aktivitas jasa adalah jarak yang tersedia ditempuh oleh seseorang dengan kondisi aksesibilitas untuk mendapatkan suatu jasa pelayanan (Daldjoeni, 1992).

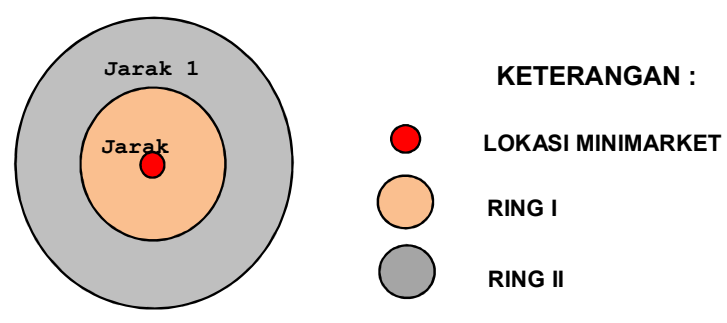

\section{Gambar 1}

Sumber : Mardiyanto, 2007

Radius Jangkauan Pelayanan Minimarket

\section{HASIL ANALISIS DAN PEMBAHASAN}

Wilayah penelitian ini adalah Kawasan Mijen yang meliputi 3 wilayah kelurahan yaitu Kelurahan Jatisari, Kelurahan Mijen, dan Kelurahan Wonolopo. Berikut adalah batas-batas wilayah penelitian sebagaimana dapat dilihat pada Gambar 3.5 berikut ini yaitu: 
* Sebelah Utara Kel. Ngadirgo dan Kel. Jatibarang

* Sebelah Selatan : Kel. Cangkiran, Kel. Tambangan,

* Sebelah Barat $\quad$ : Kel. Wonoplumbor dan Kab. Kendal

* Sebelah Timur : Kel. Jatibarang dan Kel. Purwosari

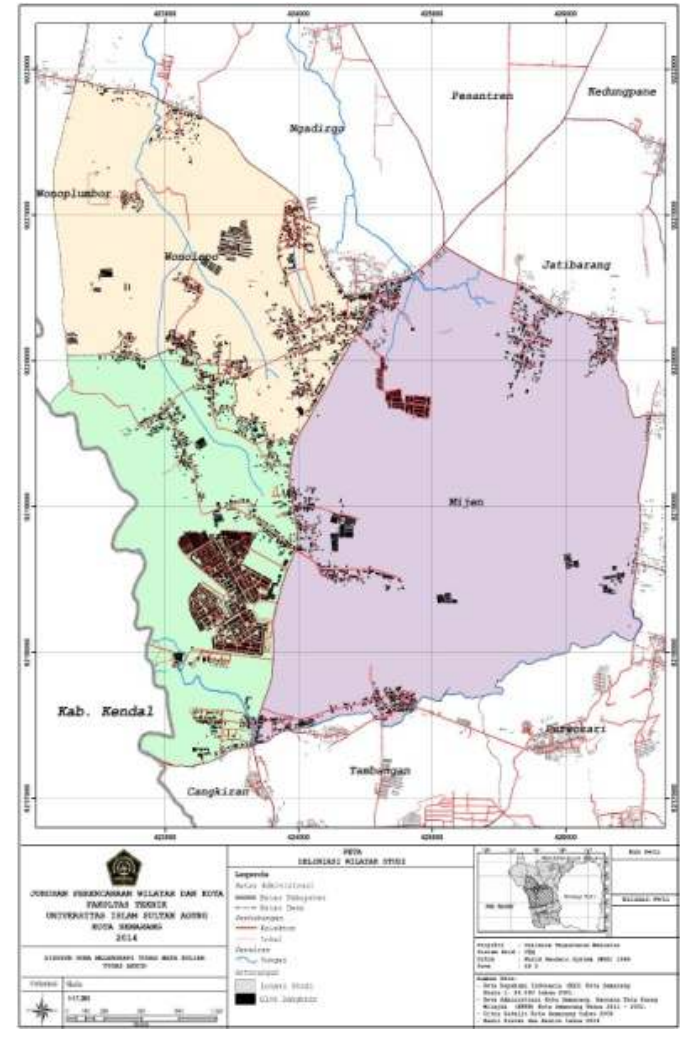

Gambar 2

Peta Delineasi Wilayah Studi
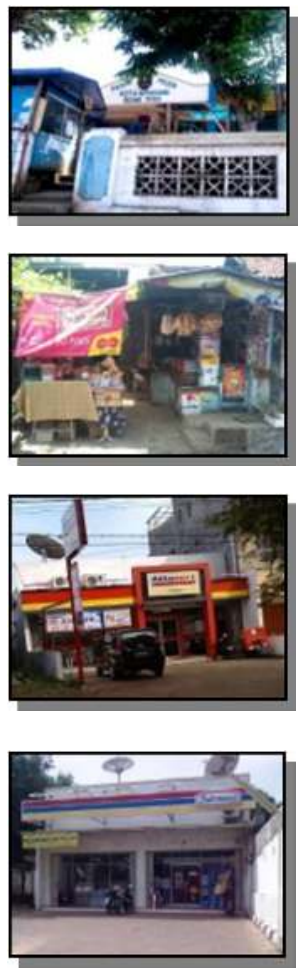

Gambar 3

Fasilitas Perdagangan

Tabel 1. Jumlah Minimarket di Kawasan Mijen

\begin{tabular}{|c|l|c|c|c|c|}
\hline No & \multicolumn{1}{|c|}{ Kelurahan } & $\begin{array}{c}\text { Kios/War } \\
\text { ung/Toko }\end{array}$ & Pasar & $\begin{array}{c}\text { Minimar } \\
\text { ket }\end{array}$ & Jumlah \\
\hline 1 & Kel. Jatisari & 76 & 1 & 4 & $\mathbf{8 0}$ \\
\hline 2 & Kel. Mijen & 38 & - & 2 & $\mathbf{4 0}$ \\
\hline 3 & Kel. Wonolopo & 64 & - & 1 & $\mathbf{6 6}$ \\
\hline \multicolumn{2}{r}{ Jumlah } & $\mathbf{1 7 8}$ & - & $\mathbf{7}$ & $\mathbf{1 8 6}$ \\
\hline
\end{tabular}

Sumber : Kecamatan Mijen Dalam Angka, Tahun 2013

\section{Analisis Perkembangan Minimarket}

Tabel 2 Proyeksi Kebutuhan Minimarket

\begin{tabular}{|c|c|c|c|c|c|c|c|c|}
\hline \multirow[b]{2}{*}{ No } & \multirow[b]{2}{*}{ Kelurahan } & \multicolumn{3}{|c|}{ Jumlah Penduduk } & \multirow{2}{*}{$\begin{array}{c}\text { Standar } \\
\text { Penduduk } \\
\text { Minimal } \\
\text { (Jiwa) }\end{array}$} & \multicolumn{3}{|c|}{ Jumlah Minimarket } \\
\hline & & 2013 & 2019 & 2024 & & $\begin{array}{c}\text { Eksistin } \\
\text { g } 2013\end{array}$ & 2019 & 2024 \\
\hline 1 & Wonolopo & 6798 & 7654 & 8617 & \multirow{2}{*}{6000} & 1 & 1 & 2 \\
\hline 2 & Mijen & 5768 & 6494 & 7312 & & 2 & 1 & 1 \\
\hline
\end{tabular}




\begin{tabular}{|c|c|c|c|c|c|c|c|c|}
\hline \multirow[b]{2}{*}{ No } & \multirow[b]{2}{*}{ Kelurahan } & \multicolumn{3}{|c|}{ Jumlah Penduduk } & \multirow{2}{*}{$\begin{array}{l}\text { Standar } \\
\text { Penduduk } \\
\text { Minimal } \\
\text { (Jiwa) }\end{array}$} & \multicolumn{3}{|c|}{ Jumlah Minimarket } \\
\hline & & 2013 & 2019 & 2024 & & $\begin{array}{c}\text { Eksistin } \\
\text { g } 2013\end{array}$ & 2019 & 2024 \\
\hline 3 & Jatisari & 8877 & 9994 & 11252 & & 4 & 2 & 2 \\
\hline & Jumlah & 21443 & 24142 & 27181 & & 7 & 4 & 5 \\
\hline
\end{tabular}

Sumber : Hasil Analisis, 2013

Perkembangan minimarket di Kecamatan Mijen dengan jumlah 7 gerai dalam jangka kurun waktu 7 tahun dinilai cukup banyak. Serta didukung pula dengan analisis proyeksi penduduk pada kondisi aksisting tahun 2013 hingga 10 tahun mendatang yaitu 2024. Terlihat bahwa hasil proyeksi kebutuhan pelayanan minimarket di Kecamatan Mijen dinyatakan sudah cukup melayani dan cenderung jumlahnya terlalu banyak.

\section{ANALISIS PERILAKU KONSUMEN}

\section{Tabel 3. Dominasi Pola Belanja Konsumen}

\begin{tabular}{|c|c|c|}
\hline Variabel & $\begin{array}{c}\text { Jumlah } \\
\text { Responde } \\
\text { n } \\
\end{array}$ & $\%$ \\
\hline \multicolumn{3}{|c|}{ FREKUENSI KUNJUNGAN } \\
\hline $1 \mathrm{kali}$ & 34 & 34 \\
\hline 2 kali & 36 & 35 \\
\hline 3 kali & 15 & 15 \\
\hline$>3$ kali & 5 & 5 \\
\hline Setiap hari & 11 & 11 \\
\hline Total & 101 & 100 \\
\hline \multicolumn{3}{|c|}{ JENIS PRODUK YANG DIBELI } \\
\hline Makanan Ringan & 18 & 18 \\
\hline $\begin{array}{l}\text { Bahan Kebutuhan } \\
\text { sehari-hari }\end{array}$ & 52 & 51 \\
\hline $\begin{array}{l}\text { Bahan makanan } \\
\text { pokok/sembako }\end{array}$ & 20 & 20 \\
\hline $\begin{array}{l}\text { Perlengkapan pecah } \\
\text { belah }\end{array}$ & 11 & 11 \\
\hline Total & 101 & 100 \\
\hline \multicolumn{3}{|c|}{ MOTIVASI BELANJA } \\
\hline $\begin{array}{l}\text { Kebutuhan yang } \\
\text { tinggi }\end{array}$ & 26 & 26 \\
\hline Waktu yang fleksibel & 18 & 18 \\
\hline $\begin{array}{l}\text { Jarak yang } \\
\text { ditempuh }\end{array}$ & 29 & 28 \\
\hline Sesuai pendapatan & 19 & 19 \\
\hline Budaya keluarga & 9 & 9 \\
\hline Total & 101 & 100 \\
\hline \multicolumn{3}{|c|}{ KEUNGGULAN MINIMARKET } \\
\hline Harga yang murah & 17 & 17 \\
\hline $\begin{array}{l}\text { Banyak pilihan } \\
\text { produk }\end{array}$ & 26 & 26 \\
\hline $\begin{array}{l}\text { Gerai bersih dan } \\
\text { tertata }\end{array}$ & 33 & 32 \\
\hline
\end{tabular}




\begin{tabular}{|c|c|c|}
\hline Variabel & $\begin{array}{c}\text { Jumlah } \\
\text { Responde } \\
\text { n }\end{array}$ & $\%$ \\
\hline $\begin{array}{l}\text { Staf yang siap } \\
\text { membantu }\end{array}$ & 4 & 4 \\
\hline Produk bermutu & 17 & 17 \\
\hline Kemudahan parkir & 4 & 4 \\
\hline Total & 101 & 100 \\
\hline
\end{tabular}

Sumber: Hasil Analisis, 2013

a. Faktor jarak yang ditempuh $28 \%$ menjadi motivasi utama masyarakat memilih minimarket sebagai tujuan belanja;

b. Dengan kebutuhan sehari-hari 51\% yang menjadi faktor pendukung dari kebutuhan yang tinggi 26\% sebagai motivasi kedua masyarakat memilih minimarket;

c. Kenyamanan tempat belanja dengan gerai bersih dan tertata rapi $32 \%$ menjadi faktor keunggulan minimarket menurut masyarakat;

d. Kelengkapan barang dengan banyaknya pilihan produk 26\% yang dapat dipilih dalam satu tempat perbelanjaan mendasari keunggulan yang diminati masyarakat dalam tujuan berbelanja; dan

e. Sekitar $66 \%$ masyarakat memilih minimarket sebagai tujuan belanja, hal ini terlihat pada kunjuungan masyarakat ke minimarket sebanyak 2 kali - setiap harinya dalam kurun waktu 1 minggu. Sedangkan sebanyak 34\% masyarakat tradisional hanyak berkunjung 1 kali dalam 1 minggu atau satu bulan, hal ini dikarenakan masyarakat tradisional tidak terlalu menyukai berbelanja di minimarket. Masyarakat ini lebih cenderung berbelanja di pasar untuk memenuhi kebutuhan setiap harinya.

\section{ANALISIS JANGKAUAN PELAYANAN}

a. Pada peta jangkauan pelayanan minimarket berdasarkan hasil olahan data spasial dengan menggunakan sistem Informmasi Geografis (GIS) dapat terlihat bahwa ring pelayanan terbagi 2 yaitu ring 1 dengan pencapai maksimum 500 meter dan ring 2 pencapaian maksimum $1 \mathrm{~km}$. Pelayanan dari masing-masing minimarket cenderung overlapping sehingga pelayanan hanya terkonsentrasi pada pusat aktivitas tertentu saja dan tidak menyebar untuk memenuhi kebutuhan masyarakat lainnya dalam pemenuhan kebutuhan pelayanan minimarket. Terlihat dari data yang memperlihatkan bahwa sebenarnya jarak tidaklah menjadi pengaruh bagi konsumen karena sebagian besar konsumen mengakses minimarket menggunakan moda kendaraan pribadi $(47 \%$ menggunakan sepeda motor). 


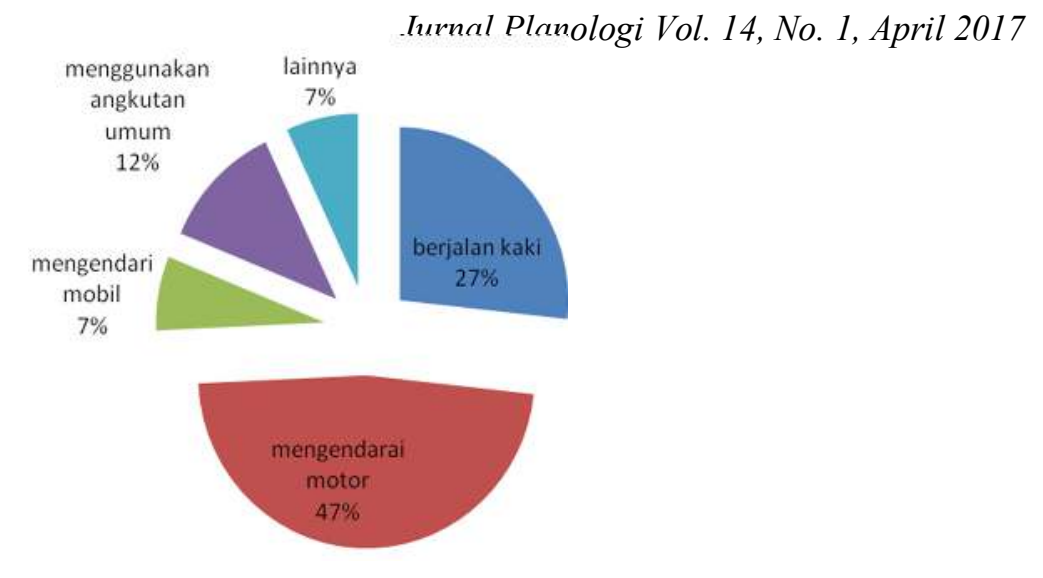

Gambar 4. Transportasi Konsumen

b. Dalam penentuan minimarket sejenis perlu adanya penelitian analisis lokasi lebih lanjut terhadap faktor yaitu 1) aksesibilitas, untuk mengetahui kemampuan kawasan tersebut dalam hal akses untuk supply barang dengan kondisi jalan yang mendukung kendaraan truk yang mengangkut barang; 2) besar permintaan, semakin tingginya jumlah penduduk maka semakin tinggi pula pelayanan ekonomi yang dibutuhkan masyarakat; 3) besarnya populasi dan karakteristik masyarakat yang ada; 4) situasi persaingan, melihat bagaimana pola belanja masyarkat yang ada; dan 5)hukum serta peraturan yang berlaku untuk penambahan pendirian minimarket atau sejenisnya di kawasan ini.

Berdasarkan segmentasi tersebut dapat dijelaskan sebagai berikut:

1. Permukiman tradisional tersebar pada zona pelayanan sekunder dan tersier. Masyarakat dapat mengakses minimarket yang terdapat di pusat pelayanan dengan menggunakan kendaraan umum atau pribadi. Hal ini sesuai dengan pola perilaku konsumen yang mendatangi minimarket sesekali untuk memenuhi kebutuhan sehari-harinya. Tidak seluruhnya masyarakat yang bermukim di permukiman tradidional mendatangi minimarket sebagai lokasi tujuan belanjanya. Salah satu faktor yang mempengaruhi hal tersebut yaitu gaya hidup yang lebih modern (dengan pendidikan minimal SMA atau Sarjana) menjadikan masyarakat enggan memilih pasar sebagai tujuan utama dalam berbelanja. Sedangkan masyarakat tradisional asli masih memilih untuk memenuhi kebutuhan pokok/sembako di pasar yang dimana letak pasar berada di tengah dan dapat melayani 3 area pelayanan.

2. Perekonomian masyarakat tradisional yang memiliki penghasilan tidak menentu seperti petani dan buruh cenderung tidak memilih minimarket sebagai lokasi tujuan belanja mereka. Masyarakat menengah kebawah cenderung berbelanja di warung atau pasar yang dimana harga barangnya dapat ditawar bahkan dapat berhutang (untuk warung terdekat rumah) untuk mendukung kebutuhan sehari-hari masyarakat ini. Hal ini karena 
perekonomian yang tidak menentu serta barang yang di jual di minimarket yang menurut mereka terlalu mahal dan tidak dapat ditawar maka masyarakat jarang sekali bahkan tidak pernah ke minimarket untuk sekedar membeli kebutuhan belanjanya.

3. Masyarakat yang bertempat tinggal di kawasan perumahan termasuk dalam golongan menengah ke atas dengan penghasilan yang tinggi dan berlatar belakang pendidikan yang tinggi pula menjadikan masyarakat di kawasan perumahan memiliki gaya hidup yang modern. Masayarakat di area perumahan mengunjungi minimarket dikarenakan lokasi yang mudah, dekat, dan dengan sgala kelebihan yang diberikan minimarket dalam hal melayani konsumen.

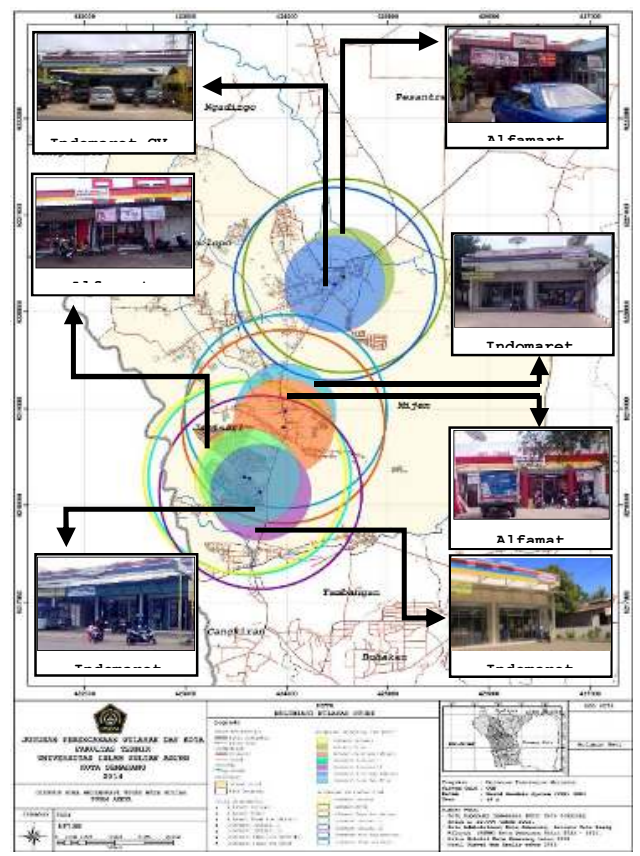

Gambar 5 Peta Jangkauan Pelayanan Minimarket Kecamatan Mijen

\section{KESIMPULAN DAN SARAN}

\section{A. Kesimpulan}

Berdasarkan hasil analisis yang dilakukan maka dapat diambil beberapa kesimpulan yaitu :

1. Kecamatan Mijen merupakan pinggiran yang ada di Kota Semarang yang merupakan kawasan pinggiran kota yang saat ini mulai berkembang pesat. Pada Kecamatan ini terdapat permukiman yang saat ini berkembang pesat terutama pada sektor perdagangan serta berpotensi dengan pertumbuhan yang semakin meningkat. Wilayah 
yang menjadi penelitian di Kecamatan Mijen ini terdiri dari Jalan Raya Mijen, Jalan RM. Hadi Soebeno Sosrowardoyo serta Perumahan Jatisari Asri.

2. Berkembangnya minimarket sangat pesat terjadi pada tahun 2009 dan 2010 , hal ini dikarenakan dalam kurun waktu 2 tahun terdapat pendirian 4 minimarket. Lokasi yang dipilih cenderung pada pusat aktivitas dan pada jalan utama penghubung Kota Semarang dan Kabupaten Kendal untuk memudahkan akses konsumen serta distribusi barang. Lahan yang digunakan peritel untuk mendirikan gerai berupa lahan kosong atau bangunan yang di sewa. Proyeksi penduduk pada kondisi aksisting tahun 2013 hingga 2024 kebutuhan pelayanan minimarket di Kecamatan Mijen dinyatakan sudah cukup melayani , 10 tahun kedepan hanya 5 minimarket untuk melayani 3 Kelurahan. Analisis konsumen diketahui bahwa sebagian besar frekuensi kunjungan dilakukan sebanyak 2 kali dalam seminggu oleh 35\% responden. Dengan jenis produk yang sering dibeli yaitu bahan kebutuhan sehari-hari 51\%. Jarak yang ditempuh cukup mempengaruhi motivasi terbesar responden untuk berbelanja di minimarket 2\% keunggulan minimarket terdapat pada gerai yang bersih serta tertata dengan rapi sekitar $32 \%$. Sekitar 66\% masyarakat yang cenderung lebih modern memilih minimarket, Sedangkan sebanyak 34\% masyarakat yang tradisional atau yang memiliki perekonomian menengah kebawah lebih cenderung berbelanja di pasar atau warung sekitar rumah untuk memenuhi kebutuhan setiap harinya; dan

3. Berdasarkan analisis tingkat aksesibilitas melalui hasil scoring disimpulkan bahwa tingkat aksesibilitas tertinggi terdapat pada koridor I (Jalan Raya Mijen).Terjadinya tumpang tindih atau overlapping antara cakupan area satu gerai minimarket dengan cakupan area gerai minimarket yang lain, akibat jarak antara satu gerai minimarket dengan gerai lainnya yang sangat berdekatan. Cakupan area yang tumpang tindih menjadikan konsumen bebas memilih dan menentukan gerai minimarket mana yang menjadi pilihan lokasi belanjanya. Bentuk jangkauan pusat pelayanan minimarket berupa lingkaran yang saling tumpang tindih dimana terdapat beberapa area yang saling beririsan atau terlayani ganda.

\section{B. Rekomendasi}

Rekomendasi yang dapat diberikan berdasarkan hasil penelitian ini adalah:

1. Sebaiknya dilakukan penataan dan pengaturan keberadaan minimarket melalui peraturan zonasi dengan memperhatikan jangkauan pelayanan minimarket. Bagi 
minimarket yang sudah beropersi perlu dilakukan peninjauan kembali oleh pemerintah dalam pengaturan dan penertiban fasilitas melalui pemberian atau pencabutan ijin mendirikan usaha dagang kepada setiap peritel sesuai dengan zona yang telah ditentukan pemerintah setempat.

2. Adanya kesenjangan supply dan demand antara fasilitas ritel dan konsumen menyebabkan ketidak seimbangan pelayanan ritel. Perlu dilakukan pembuatan perda dengan segera sebagai respon terhadap fenomena minimarket yang memuat ketentuan pendirian minimarket berdasarkan batas ambang penduduk kawasan tersebut. Hal ini untuk menghindari mekanisme pasar yang terus mempengaruhi kebijakan pemerintah;

3. Sarana-sarana perdagangan tradisional yang selama ini tersaingi secara langsung dengan minimarket (Indomaret dan Alfamart) yang belum memperhatikan faktor kenyamanan tempat belanja sebaiknya dapat membenahi kondisi sarana perdagangannya sehingga nyaman bagi konsumen dan mampu bersaing menghadapi fenomena menjamurnya Indomaret dan Alfamart; dan

4. Dapat dilakukan penelitian lanjutan mengenai fenomena menjamurnya minimarket menyangkut beberapa hal yang belum terjawab dalam penelitian ini adalah analisis aglomerasi minimarket dan alasan penentuan lokasi minimarket berdasarkan pengelolaan dan teori yang seharusnya.

\section{DAFTAR PUSTAKA}

A.C. Nielsen. 2004. Pasar Modern Terus Geser Peran Pasar Tradisional http://www.sinarharapan.co.id/ekonomi/promarketing/2004/0622/ prom1.html [diakses pada tanggal 22 Oktober 2013]

A.C. Nielsen. 2005. Asia Pasific Retail and Shopper Trends 2005, http://www.acnielsen.de/pubs/documents/Retailand ShopperTrendsAsia2005.pdf, [diakses pada tanggal 22 Oktober 2013 ].

Daldjoeni, N. 1992. Geografi Baru Organisasi Keruangan Dalam Teori dan Praktek. Bandung: Penerbit PT Alumni.

Jones, Ken \& Simmons, Jim. 1990. Location, Location, Location: Analyzing The Retail environment. Toronto: Nelson Canada.

Kotler, Philip Amstrong, Gary. 2008. Prinsip-prinsip Pemasaran (Edisi Kedua Belas) Jilid 1. Jakarta : Erlangga

Ma'aruf, Hendri. 2005. Pemasaran Ritel. Jakarta : PT. Gramedia Pustaka Utama 
Mardiyanto, 2007. Rahasia Sukses Bisnis Minimarket. Jakarta: PT. Gramedia Pustaka Utama

Mowen, Jonh C, Michael Minor. 2002. Perilaku Konsumen Edisi Kelima Jilid 1. Alih Bahasa : Lina Salim. Jakarta : Erlangga.

Sumarwan, Ujang. 2004. Perilaku Konsumen, Jakarta: Ghalia Indonesia

Aulia Astri S, dkk. 2009. Pola Distribusi Spasial Minimarket di kota-kota kecil. Jurnal Perencanaan Wilayah dan Kota. 20(2), 78-94.

Dewi, Krisna, dkk. Faktor yang Mempengaruhi Perilaku Konsumen dalam Memutuskan Pembelian Andoid oleh Mahasiswa FKIP Universitas Riau.

Marina, Syahira. Setyono, Jawoto Sih. 2012. Kajian Perkembangan dan Lokasi Minimarket. Jurnal Pembangunan Wilayah dan Kota. 8(2).

Priono, Yesser. 2013. The Potentials of Tourism Product in The Development of Tangkling Tourism Village in Bukit Batu Sub-District, Central Kalimantan as an Effort to Support Environment Conservation. Jurna Prespektif Arsitektur.8(1).

Rusli, Budiman. 2011. Kebijakan Penataan Minimarket dan Pemberdayaan Pedagang Tradisional di Kota Bandung: Studi Kasus di Kawasan Pemukiman Kecamatan Antapani. Jurnal Sosiohumaniora. 13(2), 140-159.

Sari, Erna Nur Laila. 2012. Pengaruh Keberadaan Minimarket Terhadap Kelangsungan Hidup Toko Kelontong di Kecamatan Sidoarjo Kabupaten Sidoarjo. Jurnal Geografi.

Yanto, Dafed Triwahyudi Apri. 2013. Pengaruh Citra Toko Terhadap Keputusan Pembelian Konsumen pada Minimarket Alfamart Kamal. Jurnal Ilmu Manajemen. $1(4)$. 